\title{
Business English: Viewing Its Benefits in the Perspectives of Students and Alumni
}

\author{
Titien Indrianti \& Af'idatul Husniyah \\ State Polytechnic of Malang \\ E-mail: titien.indrianti@polinema.ac.id; afidahusniyah@gmail.com
}

\begin{abstract}
How to cite (in APA Style): Indrianti, T., \& Husniyah, A. (2020). Business English: viewing its benefits in the perspectives of students and alumni. Jumal Pendidikan Babasa dan Sastra, Vol. 20(2), 143-156. doi: https://doi.org/10.17509/bs_jpbsp.v20i2.33055
\end{abstract}

Article History: (Received: 24 June 2020, Revised: 1 Agt 2020, Accepted: 25 Sept 2020)

Journal homepage: http://ejournal.upi.edu./index.php/BS_JPBSP

\begin{abstract}
English has been a language for international business. Thus, English instruction should be directed to teaching communication skills necessary for business. As a vocational institution, State Polytechnic of Malang is supposed to view its English instruction from the perspectives of the students and alumni. Thus, the present study is intended to investigate the students' and alumni's perspectives on the benefits of Business English as well as their recommendation for the course. The respondents of this study are students and alumni of Business Administration Department, State Polytechnic of Malang. To tap the data, questionnaires are deployed. The data, then, are analyzed employing descriptive statistics to obtain the most and least typical responses. Findings indicate that both students and alumni take the benefit of the course. They view this subject is to prepare for their career development in the workplace. Besides, it is beneficial for their communication at the office, particularly in foreign companies. Alumni claim that their business English knowledge and skills during their college time are applicable in their workplace. The respondents mostly demand more practices on business communication skills and vocabulary teaching included in Business English courses.
\end{abstract}

Keywords: Business English; benefits; perspectives; students; alumni

\section{Bahasa Inggris Bisnis: Mengkaji Manfaatnya dalam Perspektif Mahasiswa dan Alumni}

\begin{abstract}
Abstrak-Bahasa Inggris merupakan bahasa yang digunakan dalam konteks bisnis internasional. Oleh karena itu, pengajaran bahasa Inggris seharusnya mengajarkan keterampilan komunikasi untuk bisnis. Sebagai institusi vokasi, Politeknik Negeri Malang harus melihat pengajaran bahasa Inggris dari sudut pandang mahasiswa dan alumninya. Penelitian ini bertujuan meneliti pendapat mahasiswa dan alumni tentang manfaat yang mereka dapatkan dan saran yang dapat diberikan dari pembelajaran mata kuliah Business English. Responden penelitian ini adalah mahasiswa dan alumni jurusan Administrasi Niaga, Politeknik Negeri Malang. Data diperoleh melalui kuesioner dan dianalisa secara kuantitatif. Hasil penelitian menunjukkan bahwa mahasiswa dan alumni memperoleh manfaat dari pembelajaran mata kuliah Business English. Responden lebih jauh mengungkapkan bahwa matakuliah ini diperlukan untuk mempersiapkan pengembangan karir dan untuk keperluan komunikasi di dunia kerja.
\end{abstract}

Kata kunci: Bahasa Inggris Bisnis; manfaat; perspektif; mahasiswa; alumni 


\section{INTRODUCTION}

In a globalized era like today, people without doubt are directed to interact in a wider and broader scope fast and intensively. Globalization has urged people worldwide to hand in hand enhance efficiency and productivity (Najeeb, 2012). In doing such an interaction widely and intensively, there is a medium of communication applied. English has been a medium of international business extensively used among nonnative speakers (Najeeb, 2012; Wu, 2013). Thus, the necessity to equip someone with the ability in English is highly recommended if not obligatory. Even, English has been one of the indicators to succeed in the globalization era, whether it is used as a second language (ESL) or a foreign language (EFL) (Huang, 2015). Similarly, Thitthongkam (2010) has set forth that acquiring a foreign language is of an advantage to support understanding conversations, communications, and negotiations between practitioners and foreign customers.

Acquiring English as an international language in business is not as easy as it is supposedly thought. It becomes a complex subject to learn. For Business Administration students at the tertiary level, learning English is quite problematic. This is due to the fact that those students are to focus on two different things at one time (Voyakina \&Korolyova, 2014). On one hand, they are to emphasize understanding and mastery on their subject matter. On the other hand, they are to pay attention to learning English.

As far as Business English is concerned, it is the combination of the two different subjects, that is Business and English learning. The essence of the Business English content is accommodating the two subjects. However, it is not supposed to be learning business in English. Instead, it is learning English applied in business.

Business Administration, State Polytechnic of Malang has allocated Business English in its curriculum. The time allotment is quite adequate. It can be known from the time allotted for 5-6 hours per week for each class. It signifies that the existence of Business English is essential in the curriculum of the Department so as to respond to the challenge of the today's era. So far, the teaching of Business English has covered the topics of business terms and vocabulary, business meeting and presentation, negotiating, socializing, business advertising, business launching, and several business correspondences. Those topics were provided to the students employing different sorts of method, ranging from lecture presentation to simulation. Nevertheless, after several years the true demands of the students and alumni have not been viewed yet.

The present study needs to identify what students and alumni feel about the benefit of learning Business English as indicated by their general perspectives. The findings will be of a point of departure for the improvement of the existing syllabus and materials in the department.

\section{English for Specific Purposes (ESP) VS English for General Purposes(EGP)}

Talking about English for Specific Purposes (ESP) cannot be separated from discussing about the initial intention of the ESP emergence. ESP has been developed from a combination of three essential elements: the increase of the demand to meet particular needs, the developments in the field of linguistics and educational psychology (Hutchinson \& Waters, 1991). Those experts also have clearly stated that ESP is supposed to be viewed as an approach rather than a product. In this point, ESP is not categorized as a specific sort of language or methodology nor does it comprise a specific teaching material.

Furthermore, both experts have included ESP as the branch of English as a Foreign Language (EFL). EFL is broken down into ESP and General English (GE) which the later one is taught in primary to tertiary schools. Yet again, ESP is divided into English for Science and Technology (EST), English for Business and Economics (EBE), and English for Social Science (ESS). Under those three branches (EST, EBE, and ESS), there are English for Academic Purposes (EAP) and English for Occupational 
Purposes (EOP). In support to what Hutchinson and Waters have underlined, Lamri (2016) puts forth that ESP is a branch of Applied Linguistics, as well as, of Teaching English as a Foreign Language (TEFL).

Previously, Islam (2011) clarifies that English for General Purposes (EGP) or the Teaching of English for No Obvious Reason (TENOR) as called by Abbot (in Islam, 2011) more emphasizes on general English language abilities. On the other hand, ESP pays more attention to special skills and needs of learners on the basis of detailed analysis of learners' professional/academic needs. EGP, according to Hutchinson and Waters (1991), relates to the English language teaching at school levels where the students are taught about the structural/grammatical elements of English language for the sake of passing the exams.

It is clear, then, that ESP bases its content on the learners' demand which they possibly apply when dealing with their work or profession. In the meantime, EGP has something to do with general skills of English which is possibly employing general topics of English in the purpose of passing school examinations.

\section{English for Specific Purposes (ESP) VS Content and Language Integrated Learning (CLIL)}

Content and Language Integrated Learning known as CLIL has been considered as a way to helping learners acquire knowledge and skills on English as a foreign language (EFL) (Goris, et.al, 2019). Given such a description, the meaning of CLIL then is overlapping.

Many English teachers and learners may confuse the definition of CLIL with that of ESP, whether they are interchangeably used terms. In fact, they are of the two striking distinct premises.

Unlike ESP, CLIL as derived from its name is using a language being the learners' native language as a means of instruction in all school levels and content subjects, such as: maths, science, art or business (Mehisto, et.al, 2012). Furthermore, they point out that it is the students to learn the language not for the sake of learning the language itself but using the language to accomplish the content subject. Similarly, Basturkmen (in Lamri, 2016) also mentions that in CLIL programs, English is not learnt for its own sake by all means; rather, it is intended to support understanding and knowledge on academic, professional and workplace environments

All CLIL programs, however, have shared something in common. On the point of view of the learners, some studies as indicated by Goris, et.al (2019) imply that CLIL programs often refer to learners with adequate proficiency on EFL, those with above-average academic performance, and those with high perseverance. Meanwhile, from the point of view of CLIL teachers, it is found that teachers are apt to devote much more time on content teaching but concentrate less on language teaching (Yang, 2016). In this sense, it is to be contrasted with the function of ESP teachers who are normally paying attention to both learners' language development and content knowledge.

Thus, it can be implied that CLIL teachers are supposedly the content teachers utilized by English as the medium of instruction. Meanwhile, ESP teachers are the English teachers tutoring English to utilize learners to acquire a good command of English.

\section{Business English Teaching}

Business English is regarded as a part of English for Specific Purposes. In the teaching of this subject, it is very vital to be concerned with its need analysis, syllabus design, course design, and materials selection and development (Zelter \& Zelter, 2010). Thus, they add that the Business English teachers are supposed to be aware of the main focus of its teaching, its specialized vocabulary, its communication skills in a business related context. It is commonly known, then, that the students taking Business Administration subject are to study business language, vocabulary, and communication (Zelter \& Zelter, 2010). 
Previous Studies on Business English

Findings of a study by Crosling and Ward (2002) state that the formal presentation usually practiced in the classroom does not really prepare students for the real communication in the real workplace. Instead, the students employ more informal communication most of the time when they work. It, in turn, requires different variety of understandings and skills.

A fact in a research shows that teleconferencing, networking for contacts and advice, presenting new ideas and alternative strategies are of crucial communication skills found in 10 multinationa chemical companies in Malaysia (Kassim and Ali, 2010).

A study conducted by Thitthongkam (2011) indicates apparent application of business English in the workplace. First, English is applied in import and export companies. Second, managers view English as important for communicating with customers, other companies, and suppliers. Third, the problems come up when it deals with customers' differences and dearth of knowledge of foreign languages that they expect to the presence of professional trainers to help them improve their skills in vocabulary and conversation.

Another investigation by Guiyu and Yang (2016) has claimed that students' main reason to have taken Business English course is employment and interest despite teaching materials not fitting their demand. Besides, it is obtained that most students feel they are lack of business knowledge and skills so that they expect that Business English courses are promoting their practical business skills. More practices and communicative skills are desired in addition to teaching method and teachers' capacity.

Hiranburana (2017) has reported that the Thai Automobile and Information Technology Industry demand its employees in different levels to have skill in reading since their work is to deal with emails reading. Hiranburana also indicates that emails' writing is more essential for those working as administrators. Meanwhile, speaking and listening is more intended by cabin crews and banking staffs.
Meanwhile, in Xie and Chen study (2019), it is found that the students taking MBA business English at Chinese University do not extensively apply English in the workplace. Instead, they mostly communicate in Chinese whereas English is only used in foreign business context. Most students have found that oral communication and listening comprehension have been the most problematic subjects to learn. It is advisable that Business English courses are connected to the real-world practice and in line with the job and business needs.

It is underlined that the demand on the Business English teaching is to be directed to have more business communication and practices. Such a course should prepare the students to be skillful and competent in their workplace.

\section{METHOD}

The present study is a quantitative research in nature. More particularly, it is a survey. A descriptive statistical procedure has been deployed to obtain the students' and alumni's perspectives in regard to the benefits of Business English teaching, their attempts to cope with the subjects and their recommendations on the courses.

\section{Respondents}

The sophomores (the second year students) and alumni majoring in Business Administration Department, State Polytechnic of Malang have been the respondents of the present study. The sampling procedures were deployed, however, so as to take the sample from population.

The cluster random sampling procedure was employed to take the sample of the students since they were assembled in class. There were 7 classes from either Diploma III program or Diploma IV program. Two classes assigned as $3 \mathrm{~A}$ Office Administration class Diploma 3 and $3 \mathrm{~A}$ Marketing class D4 have become the samples.

The respondents from the alumni were taken from those who have graduated for the past five years. Their occupation and job position have become another criterion of the selection. To take the sample from the respondents, the purposive random sampling 
procedure was employed. The data of the alumni were known from the research writer's friend lists in the social media.

\section{Instruments}

Two sets of questionnaire are distributed to collect the responses from two respondent categories. One set of questionnaires accounted for 60 sheets was provided to the students and the other set of 7 sheets was given to the alumni.

The questions in the questionnaires for students elicited the benefits and the attempt they gained from the Business English course. The questions also required their recommendation for the course.

In the meantime, the questions in the questionnaire for alumni obtained how Business English was applied in their workplace. In addition, it was also asked whether they gained benefits from Business English courses they had learnt during their college time. At the end, the alumni were to give recommendation for the better improvement of the course.

The type of questions provided in the questionnaire comprises both closed and open ended queries. In the closed type, the questions are given options based on 5 likert scale, while in the open ended type the respondents can give free responses based on what their own impression.

\section{Procedures}

The distribution of the questionnaire for the students was administered by taking into consideration of their English class schedule. Such a consideration was taken for the sake of its administration simplicity. The students responded to the questionnaire in their class under the supervision of the research writer. They were not allowed to bring the questionnaire home. There were 25 responses from Marketing class Diploma IV, and 27 others from Office Administration class Diploma III.

Since all the alumni have been away from campus and have worked in different places, the distribution of the questionnaire for the alumni was conducted after making appointment with them. The only specific criterion of the alumni selection was of those who have already worked either in particular well-known companies or institutions, or as enterpreneurs. The questionnaires for the alumni were distributed via e-mail. The responses were, then, returned via e-mail too.

\section{Data Analysis}

The first data analysis dealt with the students' responses in the questionnaire. All responses in each question were listed and grouped. The similar responses were then tabulated. From the tabulation, it was found the most and least typical responses to particular questions. The typical responses were presented in the form of percentage. It was, in turn, indicated the tendency of the respondents' perspectives towards the benefits they gained from studying Business English, their attempts to accomplish the subject, and their recommendation for the course.

Likewise, the responses from the alumni were listed and grouped. The similar responses were tabulated as well to observe the tendency of the answers. The analysis comprised the findings of how the alumni applied Business English in their workplace, the benefits of having studied Business English considered by the alumni, and the alumni's recommendation for the Business English courses

\section{RESULTS AND DISCUSSION}

\section{A. The Perspectives of $3 A$ Office Administration Students on The Benefits of Learning Business English}

It is found that $81 \%$ students think that they strongly agree that learning Business English is a necessity to improve understanding, knowledge and skills about business in English. The other 15\% students think they agree and $4 \%$ students moderately agree that it is necessary to learn Business English to develop their knowledge and skill on the subject. None says in opposite. In other words, all students definitely feel learning Business English is of a benefit. In their daily English class, the students are taught business terms and expressions. Meanwhile, some skills they frequently practice are business presentation, business meeting, business socializing, business correspondence, business 
communication, business negotiation, business advertising, and business launching. Given those knowledge and skills, the students have felt that the course has given them ability to perform English skills necessary in business. Some other typical benefits have also been indicated by the students.

The students $(85 \%)$ respond that they strongly agree that studying Business English is of a support to their future work and career. The other $15 \%$ students answer they agree with the statement. In conclusion, all students certainly are in support that skills and knowledge they have learnt from the course are of a necessity for their future job and career development in the workplace, particularly when they apply or work for international companies. The more proficient they are in English, the wider the opportunity they get for their future career.

The students' responses on the benefits of learning Business English are shown in the following table.

Table 1. The perspectives of 3 a office administration students on the benefit of learning business English

\begin{tabular}{lccccc}
\hline \multicolumn{1}{c}{ Statements } & $\begin{array}{c}\text { Strongly } \\
\text { Agree } \\
\%\end{array}$ & $\begin{array}{c}\text { Agree } \\
\%\end{array}$ & $\begin{array}{c}\text { Moderately } \\
\text { Agree } \\
\%\end{array}$ & $\begin{array}{c}\text { Disagree } \\
\%\end{array}$ & $\begin{array}{c}\text { Strongly } \\
\text { Disagree } \\
\%\end{array}$ \\
\hline $\begin{array}{l}\text { Studying Business English is necessary } \\
\text { especially to increase knowledge and } \\
\text { skill in English about business }\end{array}$ & 81 & 15 & 4 & 0 & 0 \\
$\begin{array}{l}\text { Learning Business English gives } \\
\text { benefits to my future work or career }\end{array}$ & 85 & 15 & 0 & 0 & 0 \\
\hline
\end{tabular}

In the open-ended questions 100\% students indeed believe that learning English is valuable. Furthermore, the most typical reason is that Business English course gives English skills necessary in business, like business presentation, business meeting, business socializing, business correspondence, and so forth. Eighty nine percent $(89 \%)$ students think that Business English course equip them with business terms and expressions besides providing them with communication skills in business. Fifty nine percent $(59 \%)$ students are also sure that Business English open an opportunity to get better career in the future especially when they work for international company (52\%). Fifty six percent $(56 \%)$ students assume that the course offer them English communication skills in negotiating with international customers or clients. Another reason is that Business English course makes them understand global business $(22 \%)$. In opposite, few students (4\%) also respond that Business English course may not give benefit to them since they think that they will have more interaction with Indonesian acquaintances, and they only wish to open business locally, and/or work for Indonesian company or institution requiring no English communication.

The students are typically pleased to study Business English in Business Administration Department because of some reasons. Firstly, the students (15\%) feel that the English instruction taught in the Department is organized in proper sequence ranging from the basic general English to more advanced Business English. Moreover, learning English is exciting in its own for few students $(11 \%)$. In addition, most students (59\%) put reasons that the Business English taught in the Department has equipped them with skills and knowledge possibly required in their workplace later. Some others (15\%) think Business English course has also enriched their insights and horizons about English in business.

\section{B. The 3A Marketing Students' Perspectives on The Benefits of Learning Business English}

Most students (79\%) strongly agree and the other 21\% agree that learning Business English is indeed essential particularly to enhance 
their knowledge and skills about business in English. There are no students saying disagree or strongly disagree. It signifies that all students view benefits when learning Business English.

Next, sixty seven percent (67\%) students strongly agree that learning Business English benefit them for their future work and career. The other 33\% state they agree with such benefits for their future by learning Business
English. Undoubtedly, all students (100\%) confirm that they are taking advantages from learning Business English. No students (0\%) contradict the view that Business English learning is beneficial.

The following table shows the students' responses on the benefits of learning Business English.

Table 2. The perspectives of $3 \mathrm{~A}$ marketing students on the benefit of learning business English

\begin{tabular}{cccccc}
\hline Statements & $\begin{array}{c}\text { Strongly } \\
\text { Agree } \\
\%\end{array}$ & $\begin{array}{c}\text { Agree } \\
\%\end{array}$ & $\begin{array}{c}\text { Moderately } \\
\text { Agree } \\
\%\end{array}$ & $\begin{array}{c}\text { Disagree } \\
\%\end{array}$ & $\begin{array}{c}\text { Strongly } \\
\text { Disagree } \\
\%\end{array}$ \\
\hline $\begin{array}{l}\text { Studying Business English is necessary } \\
\text { especially to increase knowledge and } \\
\text { skill in English about business }\end{array}$ & 79 & 21 & 0 & 0 & 0 \\
$\begin{array}{l}\text { Learning Business English gives } \\
\text { benefits to my future work or career }\end{array}$ & 67 & 33 & 0 & 0 & 0 \\
\hline
\end{tabular}

Just like the previous group of students, all respondents from this class $(100 \%)$ definitely believe that Business English course gives them benefits. A variety of benefits are put forth by the student respondents of the present study.

It is found that most students $(92 \%)$ think that the course provide them business communication skills in English. Besides, other business skills in English benefitted by the students are business presentation, business meeting, business socializing, business correspondence, and so on (88\%). Meanwhile, $83 \%$ students point out that Business English course provides them knowledge about terms and expressions in English for Business. Business English course is also seen to equip the students with communication and negotiating skills with international customers or clients (67\%). Fifty four percent $(54 \%)$ students think that skills and knowledge they gain from the course prepare them to get work especially in international companies. After all, 50\% students are sure that their Business English skills and knowledge open the opportunity to develop their career in international companies. Another 38\% students argue that the course has trained them with the ability to understand global business issues. Then, the other $33 \%$ students state that they are also prepared to deal with global issues in business.

Even though all students view the benefits of Business English course, 4\% students still consider that the course may not benefit them for they will interact more with Indonesian community that needs no English. Another reason is that they wish to work for themselves which possibly do not require English (4\%). Those students expect to work for government institution where English is least necessary (4\%).

\section{The Attempts of 3 A Office Administration Students to Study Business English}

The students (41\%) moderately agree that they frequently read Business English articles, such as: magazines, newspapers, tabloid, or reference books. Another 33\% students agree with the statement. Then, the rest $26 \%$ students say disagree with the statement. It indicates that $74 \%$ students frequently read business English.

Forty one percent (41\%) students moderately agree that they regularly listen to Business English news on TV, radio, or other social media. Another 33\% students think that they agree and $7 \%$ students strongly agree to regularly listen to Business English news. 
Then, the rest $22 \%$ answer "disagree". The majority of students $(78 \%)$ feel that they regularly listen to Business English news on TV, radio, and other social media.

As many as $48 \%$ students moderately agree that they have made an attempt to find out Business English readings themselves. In this sense, another $26 \%$ students agree and $15 \%$ students strongly agree to try to get business English readings on their own. In the meantime, the other $11 \%$ students think that they disagree if they have tried to find out Business English texts themselves. It seems that most students $(89 \%)$ have made attempts to search readings related to business topics.

In terms of an attempt to practice English communication, $40 \%$ students think they have tried to make communication with their friends either from domestic or foreign countries. Meanwhile, 4\% others think that they disagree to have made such an attempt. It is, however, a proof that the majority of students believe that they have tried to communicate English with their friends.

The table of the students' attempt in learning Business English is presented as follows.

Table 3. The attempts of $3 \mathrm{~A}$ office administration students on the benefit of learning business English

\begin{tabular}{lccccc}
\hline \multicolumn{1}{c}{ Statements } & $\begin{array}{c}\text { Strongly } \\
\text { Agree } \\
\%\end{array}$ & $\begin{array}{c}\text { Agree } \\
\%\end{array}$ & $\begin{array}{c}\text { Moderately } \\
\text { Agree } \\
\%\end{array}$ & $\begin{array}{c}\text { Disagree } \\
\%\end{array}$ & $\begin{array}{c}\text { Strongly } \\
\text { Disagree } \\
\%\end{array}$ \\
\hline $\begin{array}{l}\text { I frequently read articles/books about } \\
\text { business in English, like: magazines, } \\
\text { newspapers, tabloids, reference books }\end{array}$ & 0 & 33 & 41 & 26 & 0 \\
$\begin{array}{l}\text { I frequently listen to Business English } \\
\text { news on TV, radio, or other social }\end{array}$ & 7 & 30 & 41 & 22 & 0 \\
$\begin{array}{l}\text { media } \\
\text { I try to search business texts in English }\end{array}$ & 15 & 26 & 48 & 11 & 0 \\
$\begin{array}{l}\text { I try to communicate in English with } \\
\text { my friends proficient in English or with } \\
\text { my overseas friends }\end{array}$ & 19 & 41 & 37 & 4 & 0 \\
\hline
\end{tabular}

\section{The Attempt of 3 A Marketing Class Students to Study Business English}

Twenty five percent $(25 \%)$ students respectively agree and moderately agree to have frequent reading English articles and books about business, such as: magazines, newspapers, tabloids, reference books. Even, $17 \%$ students claim they strongly agreed to regularly read those texts. On the contrary, twenty five percent $(25 \%)$ others mention that they disagree to frequently read such readings. Then, the other $8 \%$ students even get strongly disagree with such an activity. It can be said, however, that the students (67\%) mostly have tried to frequently read business texts in English although there are still 33\% others hardly try to do regular reading English.
In regards to listening to business news in English, 42\% students agree that they often do such a thing. Another 25\% students think they moderately agree and 8\% students strongly agree to regularly listen to Business English news. In the meantime, $21 \%$ students say "disagree" and 4\% students strongly disagree to listen to business news in English frequently. Nevertheless, most students (75\%) are willing to make an effort to listen to Business English news despite the other 25\% who do not have wiliness to listen Business English news on their own.

As many as $33 \%$ students consider that they agree and moderately agree to have made an effort to search business English readings. In addition, 17\% students respond "strongly agree" that they try to find out articles of business in English. In contrast, 13\% students disagree and 
$4 \%$ others strongly disagree to have made such an effort. In conclusion, most students (83\%) attempt to look for readings related to business in English despite 17\% other students who do not make any attempt to read business English.

Forty six percent $(46 \%)$ students fairly share the responses of "strongly agree" and "agree" to indicate that they have attempted an effort to communicate in English with their Indonesian or overseas friends. Four percent $(4 \%)$ students feel they moderately agree that they make an effort to practice communication with friends. Meanwhile, 4\% others say that they disagree to have made such an effort. Overall, the findings indicate a challenging phenomenon that ninety six percent students $(96 \%)$ claim that they have made an attempt to be able to practice their communication either with their Indonesian friends or those from foreign countries.

The table of the students' attempt in learning Business English is presented as follows.

Table 4. The attempts of $3 \mathrm{~A}$ marketing students on the benefit of learning business English

\begin{tabular}{|c|c|c|c|c|c|}
\hline Statements & $\begin{array}{c}\text { Strongly } \\
\text { Agree } \\
\%\end{array}$ & $\underset{\%}{\text { Agree }}$ & $\begin{array}{c}\text { Moderately } \\
\text { Agree } \\
\%\end{array}$ & $\begin{array}{c}\text { Disagree } \\
\%\end{array}$ & $\begin{array}{c}\text { Strongly } \\
\text { Disagree } \\
\%\end{array}$ \\
\hline $\begin{array}{l}\text { I frequently read articles/books about } \\
\text { business in English, like: magazines, } \\
\text { newspapers, tabloids, reference books }\end{array}$ & 17 & 25 & 25 & 25 & 8 \\
\hline $\begin{array}{l}\text { I frequently listen to Business English } \\
\text { news on TV, radio, or other social } \\
\text { media }\end{array}$ & 8 & 25 & 25 & 21 & 4 \\
\hline I try to search business texts in English & 17 & 33 & 33 & 13 & 4 \\
\hline $\begin{array}{l}\text { I try to communicate in English with } \\
\text { my friends proficient in English or with } \\
\text { my overseas friends }\end{array}$ & 46 & 46 & 4 & 4 & 0 \\
\hline
\end{tabular}

\section{E. The Recommendation of $3 A$ Office Administration Students on the Business English Course}

The recommendation pointed out in the first place by the students (accounted for $22 \%$ is that the Business English materials are supposed to be fascinating to the students. The topics are expected to be in accordance with the present situation so that what is being discussed in class is not out of date. Some students (4\%) also expect to have more Business English materials than the general ones, especially dealing with international business issues (4\% students).

Furthermore, the class also should be supported with an interesting atmosphere (15\% students), and teaching methods (15\% students). The students are supposed to be more stimulated to practice a lot $(19 \%$ students) and communicate using English (11\% students). The emphasis of the language learning probably focus more on vocabulary for business (19\% students) and speaking ability (11\% students). It will be better that all teachers share similar targets and teaching concepts among them (4\%) so that the output among the classes is similar as well.

The other important factor to enhance the better teaching and learning of Business English is the support of facilities (11\% students). It will be more expected that native speakers can be attended in order to provide opportunities for the students to practice with them ( $4 \%$ students). Sometimes, it is also possible that the teaching and learning activities are run out-door to refresh both the teacher and the students ( $4 \%$ students).

\section{F. The Recommendation of 3 A Marketing Class Diploma IV}

Most students (21\%) propose that the teaching and learning process in the classroom is to be more interesting and effective. It should be held up with interesting 
learning atmosphere (13\% students). Similar to the other class sample, it is expected that native speakers are invited to support the Business English learning in the department.

The focus of the learning is supposed to be more on vocabulary enrichment $(13 \%$ students). It is expected as well that communication practice will be more emphasized (4\% students). Moreover, some students (4\%) wish to get more Business English skill practices.

In terms of the materials, it is hoped that the topics are more focused on the recent business issues ( $4 \%$ students), especially touching on the analysis of the case study in business (4\% students). The issues on global business are also encouraged (4\% students).

The recommendations from both class samples sound challenging and energizing, though, to facilitate and encourage the students' proficiency in English particularly related to business topics which become their major. In spite of some intriguing inputs from the students, it does not mean the existing English instruction in the Department disappoint them

\section{G. The Alumni's Perspectives on the Application of Business English in the Workplace}

The findings from the alumni's questionnaires have found some crucial points. The respondents selected in the present study have worked in different institutions or workplaces with different kinds of occupations. The following is the table of the respondents' initials, the workplaces and their position.

Table 5. The alumni's workplace and occupation

\begin{tabular}{lll}
\hline \multicolumn{1}{c}{ Name Initials } & \multicolumn{1}{c}{ Workplace } & \multicolumn{1}{c}{ Occupation } \\
\hline FMA & Polinema & Lecturer \\
AWR & PT. Paiton Operation \&Maintenance & Secretary Manager \\
& $\begin{array}{l}\text { Indonesia (POMI), Unit 3,7, 8. Paiton, } \\
\text { Probolinggo }\end{array}$ & \\
MRA & Gedhang Ganteng Products & Owner \\
DS & Bank BNI 46 & Customer Service Staff \\
PSA & PT PLN (Persero) & Human Resources Dept. \\
AM & PT. Aisin Indonesia Automotive (Astra & Supervisor \\
& Otopart Group) & (Section Head) \\
HAF & Badan Pemeriksa Keuangan (BPK) & $\begin{array}{l}\text { Pemeriksa Muda } \\
\end{array}$ \\
\end{tabular}

First, all respondents (100\%) feel that Business English courses they learnt during their college program provide benefits in their workplace. Despite their different occupations and offices, it is confirmed that they view the materials and skills from Business English courses in their college are still beneficial.

Related to the statement item of how the materials and skills of Business English courses are applied in their workplace, the majority of the alumni (57\%) feel that some of the materials are intensively applied. In addition, they add that their English skills are sufficient to be performed for their work. Another 29\% alumni mention that the materials of Business English are not adequately applicable in their workplace. Their English competence, however, is quite good. Only 14\% alumni claim that almost all materials are used in their work and their proficient English supports them much in the workplace.

For FMA as a lecturer, it is important to provide a material on digital English correspondence, while the skill is related to business negotiating. AWR states that the materials applied in her workplace are business correspondence, business communication and presentation. Thus, to support the competences on those subjects, it is essential to emphasize on business writing 
and speaking skills. As an entrepreneur, MRA claims that materials and skills supporting business communication and presentation are of a necessity in his work. As a bank staff, DS focuses on materials and skills of public speaking, communication skill, product selling, business presentation, and business knowledge to be applicable in her office. According to PSA who work in state-owned company of PT PLN, it is vital that the staffs there acquire presentation skills, negotiating, complaint-handling and communication skills. In addition, materials of product knowledge and offering products are necessary as well. AM, who has been as the section head, requires the staff to be proficient with their general English as proven by the TOEFL/IELTS test to have career promotion. The knowledge about global business is also essential in his company. In terms of the English skills, speaking, listening, and writing are very important in his workplace. HAF, who works in government institution, requires TOEFL Preparation as the important material to acquire in his office. Again, such an English proficiency test can be advantageous for career development. However, he adds that Business English is not much applicable in his situation since his jobs deals a lot with Indonesian government affairs.

\section{H. The Alumni's View on the Benefits of Having Studied Business English}

Related to the benefits of Business English courses, 100\% alumni claim that Business English courses have given English skills necessary for business context, such as: business presentation, business meeting, socializing in business, business correspondence, and so forth. Seventy one percent $(71 \%)$ feel the benefit in a sense that Business English courses equip them with business terms and expressions essential for their work and communication skills particularly in dealing with overseas customers or clients. Business English courses also provide alumni with communication skills in business (57\%). Next, Business English courses give the alumni a career opportunity and development especially in multinational company (43\%). In addition, the courses give insights dealing with global business $(29 \%)$.

\section{The Alumni's Recommendation on the Business English Course \\ As a lecturer, FMA suggests that English} is used as a media of communication not only related to Business English subjects but also in other subjects in the college. Since AWR frequently uses English in her office in everyday situation, like with her fellow office mates, when making report or presentation, telephoning and making correspondence, she insists on providing more practices to communicate orally or in written form. Business simulation is also suggested, in this sense. Besides, providing recent business issues to discuss in English is highly recommended. As an entrepreneur, MRA proposes more practices in English. He suggests giving more global and up to date issues in English. Case study analysis can also be teaching materials to be provided in the college. In DS's views, it is important to complement the students with business vocabulary. Similarly to the previous suggestions, she expects that more Business English practices are conducted, such as: business presentation, product selling, etc. PSA thinks that the teaching of Business English course in the Department has already been excellent. He points out an idea to have an English day which requires all the academic staffs and students to use English. It will be better if the students are shown the formal and informal language usage since it is also essential to be applied later in the real situation. He adds that he applies such a condition where English is used either in formal or informal situation with his fellow international friends. AM recommends more on the teaching of the character building even though such a suggestion seems to be somewhat irrelevant with the item being asked in the questionnaire. It is, however, a good point to insert as well in Business English courses. According to him, reducing formal hard materials which are more theoretical is also important. Instead, the 
students may be given more updated global topics related to business. Furthermore, the area to teach is not solely carried out in the classroom. It is sometimes better that outdoor area is used. For HAF as a government worker, TOEFL materials and preparations can be provided to the students. $\mathrm{He}$, in this case, refers to the most required English practice applied in his office,

\section{CONCLUSION}

The global challenge urges all individuals to be more competitive. One of the skills to acquire is communication skill. In doing communication, a global language is applied. It is English having been an international language connecting people in almost all aspects of life worldwide, including in business. Thus, international business requires English as a medium of communication.

Business Administration students and the alumni should be aware of the necessity to acquire English. At the college they have spent much time for studying Business English. At work, many of them also are to apply the business English skills and knowledge.

It is indicated clearly from the findings of the present study that most students definitely feel the benefits of studying Business English. Some typical benefits have been indicated by the students.

First of all, studying Business English is necessary for developing their understanding, knowledge and skills about business in English. Knowledge on business terms and expressions in English is of the point that many students have identified. Most students also clearly state that Business English course have enabled them to perform English skills necessary in business. Some skills to mention are particularly business presentation, business meeting, business socializing, business correspondence, business communication, and business negotiation.

The students, furthermore, think that those insight and skills will be of a necessity for their future work and career development, particularly when they apply or work for international companies. The more proficient they are in English, the bigger the prospect they have for their future career.

Understanding about global issues in business has also become the concern of the students as the benefits of studying Business English. The students state that the course has prepared them to deal with global issues in business.

Some recommendations are addressed by the students for the better development of the teaching and learning program in the Department. Most students explicitly state that the more fascinating materials are to be constructed. More materials about global business and recent issues are encouraged in this sense.

The vocabulary enrichment and business communication practice are to be maintained and emphasized. It is intended to make the students more stimulated to use the language in business.

A conducive situation supporting the atmosphere of learning Business English is touched upon by the students as well. The students should be more urged to practice English in class. They are also encouraged to use it outside the class. The invited native speakers are expected by the students to support the atmosphere. It is to motivate them to be able to communicate in English.

The alumni contribute insights and inputs to the better Business English instruction in the Department. All the sample alumni take a lot of benefits from the courses during their college time. Most of them claim to apply in their workplace what they have learnt from the courses. Some of them do not apply it, however, for their working environment does not wish them to do so.

Most of them also claim that their proficiency sufficiently support their work. Few of them confess that their English competence is sufficient but it cannot be intensively applied in their office. It is probably either due to the condition that their work does not really need their English or the materials they learn are not applicable in the company. However, there are alumni who use their English in high intensity since they work for multinational company. Luckily, their 
English is satisfactorily competent. One more point underlined by the alumni is that English is used for the development of the career in the company.

The alumni have suggested that business communication skills in English should be more practiced. The skills to emphasize are those of business presentation and meeting, making business correspondence and report, and product selling. In addition, the usage of formal and informal language should be taught to the students so that they can apply the language based on the situation.

All the phenomena of sorts of demanded English competences at work found in the present study have been in line with some studies as mentioned earlier. The most intended competencies are of English related to practical business and communicative skills (Thittongkam, 2011; Guiyu and Yang, 2016; Xie and Chen, 2019)

The alumni's responses mentioning that formal and informal usage of English should be taught is somehow in line with a study by Crosling and Ward (2002) showing that most of the oral communication applied in the workplace is informal in nature.

It is indicated as well that business terms and vocabulary is stressed on since it is one of the points in the teaching of Business English. This point of view is completely relevant to a study by Zelter and Zelter (2010).

\section{ACKNOWLEDGEMENTS}

The present research has been fully funded by Research and Community Service Unit (P2M) of State Polytechnic of Malang.

\section{REFERENCES}

Crosling, G., \& Ward, I. (2002). Oral Communication: The Workplace Needs and Uses of Business Graduate Employees. English for Specific Purposes, 21(1), 41-57.

Goris, J., Denessen, E., \& Verhoeven, L. (2019). The contribution of CLIL to learners' international orientation and
EFL confidence. The Language Learning Journal. 47(2), 246-256.

Guiyu, D., \& Yang, L. (2016). An Empirical Study on Business English Teaching and Development in China-A Needs Analysis Approach. Higher Education Studies, 6(2), 142-153.

Hiranburana, K. (2017). Use of English in the Thai Workplace. Kasetsart Journal of Social Sciences, 38 (2), 31-38.

Huang, D.F. (2015). Exploring and Assesing Effectiveness of English Medium Instruction Courses: The Students Perspectives, Procedia Social and Behavioral Sciences, 173(2015), 71-78.

Hutchinson, T., \& Waters, A. (1991). English for Specific Purposes: A Learning Centered Approach. Cambridge: Cambridge University Press.

Islam, M. (2011). The Differences and Similarities between ESP \& EGP teachers. Asian EFL Journal. Retrieved October 15, 2019, from httppu.edu.pkimagesjournalenglishPDF 4. $\% 2520 \mathrm{ESP} \% 2520 \mathrm{vs} \% 2520 \mathrm{EGP} \% 25$ 20Teacher $\% 2520$ Article $\% 2520$ after $\% 2$ 520revision\%252013-12-14.pdf.).pdf

Kassim, H., \& Ali, F. (2010). English Communicative Events and Skills Needed at the Workplace: Feedback from the Industry. English for Specific Purposes, 29(1), 168-182.

Lamri, E.C. (2016). An Introduction to English for Specific Purposes. Abou Bekr Belkaid University.

Mehisto, P., Marsh, D., \& Frigols, M.J. (2012). Uncovering CLIL: Content and Language Integrated Learning in Bilingual and Multilingual Education. Oxford: Macmillan Education.

Najeeb, S.S.R. (2012). The Business of Teaching English as a Second Language: A Libyan Case Study. Procedia Social and Behavioral Sciences, 70 (2013), 1243-1253.

Thitthongkam, T. (2011). The Roles of Foreign Language in Business Administration. Journal of Management Research, 3(1), 1-15.

Voyakina, E.Y., \& Korolyova, L.Y. (2014). To the Problem of Teaching Business 
English as English for Specific Purposes in Higher Educational Institution. УНИВЕРСИТЕТ им. В.И. ВЕРНААСКОГО, 50(1), 47-55.

Wu, Y. (2013). Business English as a Lingua Franca (BELF). International Education Studies, 6(10), 130-137.

Xie, Q., \& Chen, J. (2019). The English Communication and Learning Needs of Master of Business Administration Students and Curriculum Development at a Chinese University. SAGE. 1(16), 2-16, Retrieved October 11, 2019.
file:///E:/Academic\% $\% 20$ Circle $\% 20$ Oct $\% 202019 /$ Articles $\% 20$ on $\% 20$ Problems $\% 20$ in $\% 20$ Business $\% 20$ English $\% 20$ tea ching $\% 20$ and $\% 20$ Learning/215824401 9835951.pdf

Yang, W. (2016). ESP vs. CLIL: a coin of two sides or a continuum of two extremes? ESP Today, 4(1), 43-68.

Zelter, D.Z., \& Zelter, S.Z. (2010). Teaching Business English-a Challenge both for Students and Academics. Procedia Social and Behavioral Sciences, 3(2010), 245-250. 